\title{
Myxomycete diversity on Cryptomeria japonica bark varies with land-use type along montane rivers
}

\section{Kazunari Takahashi, ${ }^{1}$}

\author{
1 Kurashiki City College, 160 Hieda-cho, Kurashiki city, \\ Okayama 711-0937, Japan \\ ${ }^{*}$ Corresponding author: \\ kumakusu03@yahoo.co.jp \\ Keywords: Corticolous myxomycetes, Forest depletion, \\ Land-use type, Moist chamber culture, River basin, \\ Species diversity \\ Article info: \\ Received: 27 February 2021 \\ Accepted: 13 June 2021 \\ Published online: 23 August 2021 \\ Corresponding Editor: Riikka Linnakoski
}

\section{Abstract}

Myxomycetes occur globally, but little is known about the mechanism by which myxomycete diversity and community structure respond to environmental gradients and human activity at local scales. The present study assessed the distribution of corticolous myxomycetes living on the bark of Cryptomeria japonica trees along three rivers originating in the Chugoku Mountains in western Japan. Bark samples were collected from 14 sites along each river, which encompass the river sources as well as the upper, middle, and lower reaches. The environmental characteristics of each site were assessed for three variable types: geography, climate, and land-use. A $1 \mathrm{~km}^{2}$ grid was superimposed onto each survey site, consisting of 100 cells of 1 ha each, and each cell was classified using aerial imagery into a broad land-use type. Of these, three land-use types (forest, farmland, and residential) were regularly used as a comprehensive indicator of landscape. The bark samples were cultured using the moist chamber technique, and the resulting myxomycete fruiting bodies were identified. Sporophores formed on $96 \%$ of the 1,490 moist chamber cultures and 
were classified into 27 taxa (26 species and one variety). Species diversity was highest in natural forests near river sources and decreased with proximity to downstream estuaries. Community similarities between survey sites were analysed using non-metric multidimensional scaling (NMDS). The first NMDS axis was negatively correlated with distance from estuary and forest coverage. Indicator species were identified for environmental changes along river basins. The relative abundances of Macbrideola argentea, Hemitrichia velutina, and Physarum nutans var. rubrum were positively correlated with forest coverage. In contrast, the relative abundances of Clastoderma debaryanum, Diderma chondrioderma, and Echinostelium minutum were positively correlated with residential area coverage. The distribution of corticolous myxomycetes on C.japonica trees was associated with local landscape changes along the river environments. This is the first report on myxomycetes assemblages along river basins (acting as ecological corridors) and indicates that forest degradation and land-use types strongly affect myxomycete diversity on the bark of living $C$. japonica trees.

\section{Introduction}

Myxomycetes are eukaryotic fungus-like protists that engulf bacteria as their primary source of nutrients. Many species are associated with wood and plant debris, and play important roles as scavengers or decomposers of decaying plant debris (Stephenson 2011), which is important in controlling the material cycle in terrestrial ecosystems. As myxomycetes mainly disperse as spores by wind, they are thought to occur globally; however, myxomycete species actually only colonise preferred habitats (Schnittler \& Tesmer 2008). The corticolous myxomycetes are an ecological group of myxomycetes that exclusively live on tree bark surfaces (Gilbert \& Martin 1933), where they complete their entire life cycle (Keller \& Brooks 1973).

Recent studies have suggested that geographic ranges of myxomycetes are limited by regional climate and vegetation (Schnittler et al. 2000; Rollins
\& Stephenson 2011; Lado et al. 2016; Dagamac et al. 2017), and that myxomycetes may follow the moderate endemism model (Stephenson et al. 2008). Some myxomycetes are likely to have restricted ranges based on preferences for different habitats with varied climates and substrates (Estrada-Torres et al. 2013; Aguilar et al. 2014). For example, Physarum pseudonotabile Novozh., Schnittler \& Okun has been found in extreme habitats and described as being a xerotolerant species that inhabits the bark of living plants and ground litter in arid regions (Novozhilov et al. 2013). Myxomycete geographic distribution has been examined in a few studies at local scales (Macabago et al. 2017; Novozhilov et al. 2018; Takahashi et al. 2020), but there remains a lack of detailed insight about how their association with a region is affected by local environmental factors. The local climate, geographical features, and impacts from human activity could all affect myxomycete distribution and abundance.

The Japanese archipelago has many geological and topographic features creating various local environments, making it an ideal region to investigate myxomycete distribution patterns. Rivers in Japan create deep valleys, which are accompanied by varied natural environments and vegetation. They run from upper montane regions to estuaries, with the longest river in the country only $210 \mathrm{~km}$ in length. The environments along the rivers and associated streams produce varied habitats for many organisms as well as human occupation. Land use has historically changed the natural environment and influenced species distribution and biodiversity along rivers. For example, Cryptomeria japonica (Thunb. ex. L. f.) D. Don trees, which originally preferred humid locations, have been widely planted in the mountains and along rivers because $C$. japonica trees are useful for timber production; the forestry industry has extended many planting areas.

Corticolous myxomycetes grow abundantly on the bark of $C$. japonica trees in the Japanese archipelago: approximately 30 species have been identified in previous studies (Takahashi \& Harakon 2018; Takahashi et al. 2018). The trunks of $C$. japonica are flat with fibrous and furrowed bark, which is suitable for trapping wind-dispersed spores and providing habitat for myxomycetes; however, little is known about how local geographical and climatic 
environments, including land-use types, influence the community structure and species distribution of myxomycetes. A river basin is an ecological corridor from river source to estuary and is composed of various natural environmental factors and human activities. The objective of this study was to identify myxomycete distribution patterns and diversity on the bark of $C$. japonica trees growing along rivers in western Japan.

\section{Materials and methods}

\section{Survey sites}

Three class A rivers, the Yoshii River, the Asahi River and the Sendai River, in the Chugoku district in western Japan, were set for basin survey (Fig. 1) because they flow toward the north or south from the Chugoku Mountains (approximately 1,200 m altitude) to estuaries downstream of, and near to, urban

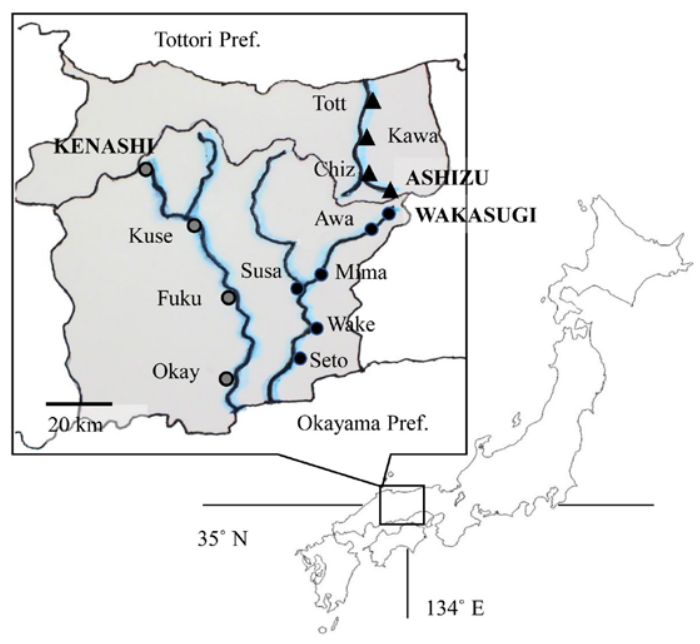

Fig. 1. Locations of 14 survey sites along three rivers in Okayama Prefecture and Tottori Prefecture in western Japan. Code names for survey sites are provided in Table 1. Symbols indicate three rivers, $\boldsymbol{\Delta}$ : Sendai River, Yoshii River, $\mathbf{O}$ : Asahi River. The source of each river is in the Chugoku Mountains. areas. Information on the river environment was obtained from the Ministry of Land, Infrastructure, Transport, and Tourism (https://www.mlit.go.jp/ river/toukei_chousa/kasen/jiten/nihon_kawa/07_ chugoku.html, accessed April 2019). There is preserved natural forest of $C$. japonica at the source of each river. The Sendai River extends $52 \mathrm{~km}$, running through Tottori Prefecture in the north to the Sea of Japan. To the south, the Yoshii River extends 130 $\mathrm{km}$ and the Asahi River extends $142 \mathrm{~km}$. Both run through Okayama Prefecture to the Setouchi Inland Sea. The various landscapes surrounding these three rivers contain natural $C$. japonica forests in their reaches and $C$. japonica plantations scattered along the river basins.

Survey sites were selected at several points along each river that encompass the river sources as well as the upper, middle, and lower reaches. Sample sites included native forests in the Chugoku Mountains and plantations, shrines, and green parks along the river basins. Four sites were established along the Sendai River, six along the Yoshii River, and four along the Asahi River (Fig. 1). Survey site information, including geographical locations, climate variables, and landscape types, is described in Table 1.

Temperature and precipitation data for each survey location were obtained from the Japanese Meteorological Agency (http://www.data.jma.go.jp/ obd/stats/etrn/index.php?sess, accessed on March 2020) observations from neighbouring areas, and calculated for study sites based on a temperature decrease rate of $-0.55^{\circ} \mathrm{C}$ per $100 \mathrm{~m}$ gain in elevation. The mean annual temperature across the study area ranged from $7.6-16.2{ }^{\circ} \mathrm{C}$ and the mean lowest monthly temperature ranged from $-4.7-4.9^{\circ} \mathrm{C}$. Regional mean annual precipitation ranged from 1,106-1,924 mm.

\section{Environmental gradients and land-use types}

The 14 survey sites were assessed for three environmental variable types: geography [distance from estuary ( $\mathrm{km})$, latitude ( ${ }^{\circ}$ north), longitude ( ${ }^{\circ}$ east), and altitude $(\mathrm{m})$ ], climate [annual mean temperature $\left({ }^{\circ} \mathrm{C}\right)$, lowest month mean temperature $\left({ }^{\circ} \mathrm{C}\right)$, and annual precipitation $(\mathrm{mm})]$, and land-use.

Land-use types were assessed using aerial im- 
agery and an associated classification scheme from the Geographical Survey Institute (http://maps.gsi. go.jp/, accessed September 2019). Each survey location was overlaid by a $1 \mathrm{~km}^{2}$ grid, consisting of 100 cells of 1 ha each, and each grid cell was categorised into one of six broad land-use types: forest, farmland, residential, empty space (wasteland, vacant lots, and roads), water, and industrial. Each cell was assigned a land-use type if $>50 \%$ of the cell was occupied by that type, and cumulatively counted within each $1 \mathrm{~km}^{2}$ grid. Land-use types that occupied $\leq 3 \%$ of the grid were excluded from the analysis, as they were considered insignificant and without meaningful association with the distance from estuary metric. In this study, three land-use types (forest, farmland, residential) were regularly used as a comprehensive indicator of landscape, as indicated in Table 1.

\section{Bark sampling}

Bark was sampled over two to three days between May and November of 2019 along each river. Samples were collected from 10 to 13 trees at each site (149 trees in total). Trees with stem diameters at breast height (DBH) over $20 \mathrm{~cm}$ were selected for sampling. The outer bark was peeled off by hand from the stem surface at a height of $50-200 \mathrm{~cm}$ from the ground and placed in a paper bag. Bark that was attached to the surface by moss or lichen was excluded from sampling.

\section{Myxomycete cultures}

Moist chamber (MC) cultures were prepared using plastic Petri dishes $(9 \mathrm{~cm}$ diameter) following the protocol of Takahashi et al. (2018). Ten cultures were prepared per tree, resulting in a total of 1490 MC cultures. Bark samples were air-dried for 1-2 weeks at ambient temperature then cut into pieces 3-8 $\mathrm{cm}$ in length. Approximately $5 \mathrm{~g}$ of bark (dry weight) was placed on clean filter paper in each dish; outer surface of the bark was upper side, and soaked with approximately $25 \mathrm{~mL}$ distilled water ( $\mathrm{pH}$ 6.9) for 3 days. The chemical properties of the bark were assessed by measuring the $\mathrm{pH}$ and electrical conductivity (EC) of the resulting exudate, using a compact $\mathrm{pH}$ and EC meter (Horiba, Kyoto, Japan).
The $\mathrm{EC}$ and $\mathrm{pH}$ values per tree were respectively estimated as the mean and median of five exudate samples in a random manner, and then the average values per site were calculated.

Next, excess water from each MC dish was drained and the dishes were incubated for three weeks at $23{ }^{\circ} \mathrm{C}$ to stimulate sporulation. Then, the dishes were kept with their lids halfway open to dry the bark samples. When fruiting bodies appeared in the MC, they were observed using a stereomicroscope. Myxomycete species were identified through morphological characteristics of the fruiting body and spore characterisation as described by Yamamoto (1998), and followed the nomenclature of the most recent literature (Lado 2005-2020). Voucher specimens were prepared using separate paper boxes for each species. Bark with myxomycete fruiting bodies were glued to the bottom of each box, and collection boxes were stored in the laboratory.

\section{Data analyses}

Species richness and abundance were determined for each survey site. Sampling adequacy (percentage of exactitude) was assessed by dividing the number of species observed $\left(S_{\text {obs }}\right)$ within a site by the estimated number of species $\left(S_{\text {est }}\right)$ using the Chaol estimator (Chao 1984) and PAST software (Hammer et al. 2001). To quantify myxomycete species diversity at different sites, the Shannon-Wiener diversity index, $H$, (Shannon \& Weaver 1963) and equitability, $J$, were calculated, following previous studies of myxomycetes (Stephenson 1989).

The abundance of a species was estimated using the number of positive culture dishes in which sporangia appeared on the bark. The percentage of positive cultures was calculated by dividing the number of dishes with successful cultures (i.e. those with sporangia) by the total number of dishes. Relative abundances were calculated by dividing a given species' abundance by the cumulative abundance of the site's community (Stephenson et al. 1993). We defined common species as those that appeared at every site, and dominant species as those with $>10 \%$ relative abundance at the site community level. The influence of environmental factors on relative abundances was examined with correlation analysis. 
Table 1. Geography, climate and land-use types at survey sites along three class A rivers flowing from the Chugoku Mountains. Site names written in capital letters are river sources.

\section{Yoshii river}

Code of Survey site ${ }^{*}$ WAKA Awak Mima Susa Wake

\section{Geography}

Distance from estuary $(\mathrm{km})$ 133 116 68

66

41

10

\begin{tabular}{|c|c|c|c|c|c|c|}
\hline North latitude $\left({ }^{\circ}\right)$ & 35.2518 & 35.1503 & 34.9349 & 34.9181 & 34.8067 & 34.6948 \\
\hline East longitude ( ${ }^{\circ}$ ) & 134.3932 & 134.3312 & 134.1258 & 134.0961 & 134.1588 & 134.1012 \\
\hline Altitude (m) & 1050 & 298 & 58.8 & 48.3 & 23.9 & 9.9 \\
\hline \multicolumn{7}{|l|}{ Climate } \\
\hline Mean temperature $\left({ }^{\circ} \mathrm{C}\right)$ & 8.4 & 12.5 & 14.2 & 14.2 & 14.0 & 14.8 \\
\hline Lowest month temperature $\left({ }^{\circ} \mathrm{C}\right)$ & -4.4 & -0.2 & 1.9 & 1.9 & 2.5 & 3.9 \\
\hline Annual precipitation ( $\mathrm{mm})$ & 1647 & 1647 & 1416 & 1416 & 1174 & 1086 \\
\hline \multicolumn{7}{|l|}{ Land-use types (\%) } \\
\hline Forest coverage & 100 & 80 & 54 & 42 & 40 & 30 \\
\hline Farm coverage & 0 & 18 & 16 & 23 & 21 & 44 \\
\hline Residence coverage & 0 & 2 & 15 & 15 & 22 & 21 \\
\hline
\end{tabular}

*Codes for survey site names are provided.

WAKA: Wakasugi natural forest at Yoshii river source, Awa: Nishiawakura, Mima: Fukumoto at Mimasaka shi, Susa: Susai at Akaiwa shi, Wake: Wake chyo, Seto: Osafune chyo at Setouchi shi, KENA: Mt. Kenashi of Shinjou son at Asahi river source, Kuse: Kuse at Maniwa shi, Fuku: Fukuwatari at Okayama shi, Okay: Tsushima at Okayama shi, ASHI: Ashizu valley at Sendai river source, Chiz: Chizu chyo,

Kawa: Kawahara chyo, Tott: Uemachi at Tottori shi. 
Asahi river

KENA Kuse

Fuku

Okay

16

52

38

22

10

35.2290

133.5226

782

99

41

35.0872

$133.7443 \quad 133.9026 \quad 133.9194$

189

69

13.3

1.8

2.3

4.9

1106

1432

1240

53

53

15

30

19

$\begin{array}{ll}11 & 15 \\ 19 & 30\end{array}$

4

96
0
4

\section{Sendai river}

$\begin{array}{llll}\text { ASHI } & \text { Khiz } & \text { Kawa } & \text { Tott }\end{array}$




\section{Ordination of myxomycete communities}

Non-metric multidimensional scaling (NMDS; Kenkel \& Orlóci 1986) was performed for the 14 myxomycete communities based on Bray-Curtis dissimilarities (Bray \& Curtis 1957), wherein higher values (to a maximum of 1.0) indicate greater dissimilarity between communities in terms of species composition and abundance. The NMDS was performed using PAST software (Hammer et al. 2001) based on its effectiveness in a similar study (Takahashi \& Harakon 2016). Then, correlation analyses were conducted between the first two NMDS axes and environmental variables, such as environmental gradients, latitude, longitude, altitude, annual mean temperature, lowest monthly mean temperature, annual precipitation, tree traits $(\mathrm{DBH}$, bark $\mathrm{pH}$, and EC), and land-use types to identify important environmental factors for understanding myxomycete ecological features. Significant environmental variables affecting the community ordination were further assessed by correlation with species relative abundances of the 14 communities to determine distribution patterns of species corresponding to environmental variables.

\section{Results}

\section{Environmental gradients along rivers}

The environment factors present at each river are presented in Table 1, in order from the site at the river source to the site closest to the estuary. Distance from estuary positively correlated with altitude $(r=0.603, p<0.05)$ and was also significantly correlated with annual mean temperature $(r=-0.655, p<$ $0.05)$, lowest monthly mean temperature $(r=-0.791$, $p<0.01)$, forest coverage $(r=0.717, p<0.01)$, and residential coverage $(r=-0.599, p<0.05)$. Landscape coverage with forest was greatest in montane sites but decreased closer to the estuaries with increasing residential and farmland coverage (Fig. 2).

Traits of sampled trees are shown in Table 2. The DBH ranged from $39-104 \mathrm{~cm}$ and did not significantly correlate with altitude $(r=0.537)$, bark
$\mathrm{pH}(r=-0.392)$, or EC $(r=-0.084)$. Bark pH ranged from 3.5-4.1 and EC ranged from $92-493 \mu \mathrm{S} / \mathrm{m}$ (Table 2). There was no correlation between $\mathrm{pH}$ and EC $(r=-0.089)$; however, bark $\mathrm{pH}$ had a significant negative correlation with forest coverage $(r=-0.731$, $p<0.01)$. The environmental variances selected as affective factors for environmental gradients were distance from estuary, altitude, annual mean temperature, forest coverage, and residential coverage, in addition to bark $\mathrm{pH}$.

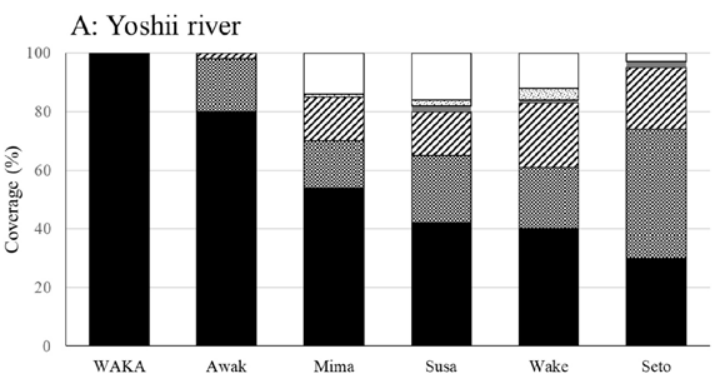

B: Asahi river
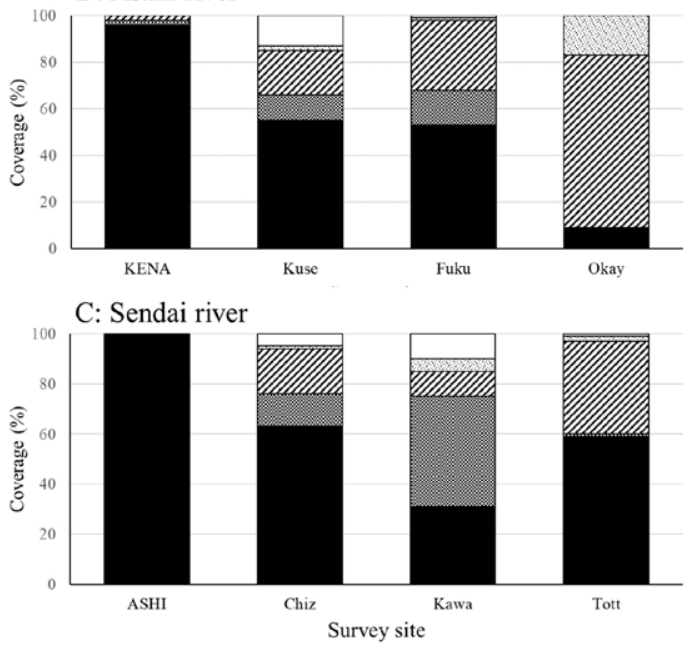

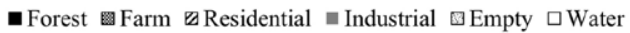

Fig. 2. Composition of land-use types in survey sites along the three rivers. A: Six sites along the Yoshii River, B: Four sites along the Asahi River, C: Four sites along the Sendai River. Land-use was categorised into the following six types: forest, farmland, residential, industrial, empty space, and water. Land-use type is indicated by percentage of area in $1 \mathrm{~km}^{2}$.

Code names for survey sites are provided in table 1. 


\section{Myxomycete species diversity}

Myxomycete fruiting bodies developed in $82-100 \%$ of the sites and in $96 \%$ of the 1,490 total MC cultures. Species richness per tree ranged from 3.9-7.8, which was positively correlated with distance from estuary $(r=0.800, p<0.01)$, altitude $(r=0.698, p<0.01)$, and forest coverage $(r=0.689, p<0.01)$. Species richness per site ranged from $8-15$ species, comparable to the number of species estimated by Chao-1, which indicated $95 \%$ accuracy. Species richness was negatively correlated with latitude $(r=-0.620, p<0.05)$. Species diversity $\left(H^{\prime}\right)$ ranged from $1.62-2.27$, which was significantly correlated with the distance from estuary $(r=0.552, p<0.05)$, and correlated with equitability $\left(J^{\prime}\right)$ values ranging from $0.74-0.88(r=0.820, p<0.01)$.

Twenty-seven taxa (26 species and one variety) were recorded and are arranged in order of relative abundance in Table 3. The most abundant species, which were recorded at every site and contributed to $>10 \%$ of the relative abundance, were Paradi- acheopsis rigida (Brândǎ) Nann.-Bremek. (22\%), Cribraria confusa Nann.-Bremek. \& Y. Yamam. (17\%), Arcyria cinerea (Bull.) Pers. (13\%), and Enerthenema melanospermum T. Macbr. \& G.W. Martin (11\%). Physarum nutans Pers. also appeared at every site with a relative abundance of $6 \%$. Thirteen taxa had relative abundances of $1-6 \%$ and there were nine rare taxa, with $<1 \%$ relative abundance.

\section{Ordination of myxomycete communities}

Similarities among 14 myxomycete communities (i.e., site-level communities) were evaluated using NMDS analysis (Fig. 3). In the ordinations, the upriver communities were arranged on the negative side of the first axis, and the downstream communities were on the positive side. The six communities in the Yoshii River extended along the widest range of the first axis, following those of the Asahi River and the Sendai River.

Correlation coefficients between the first

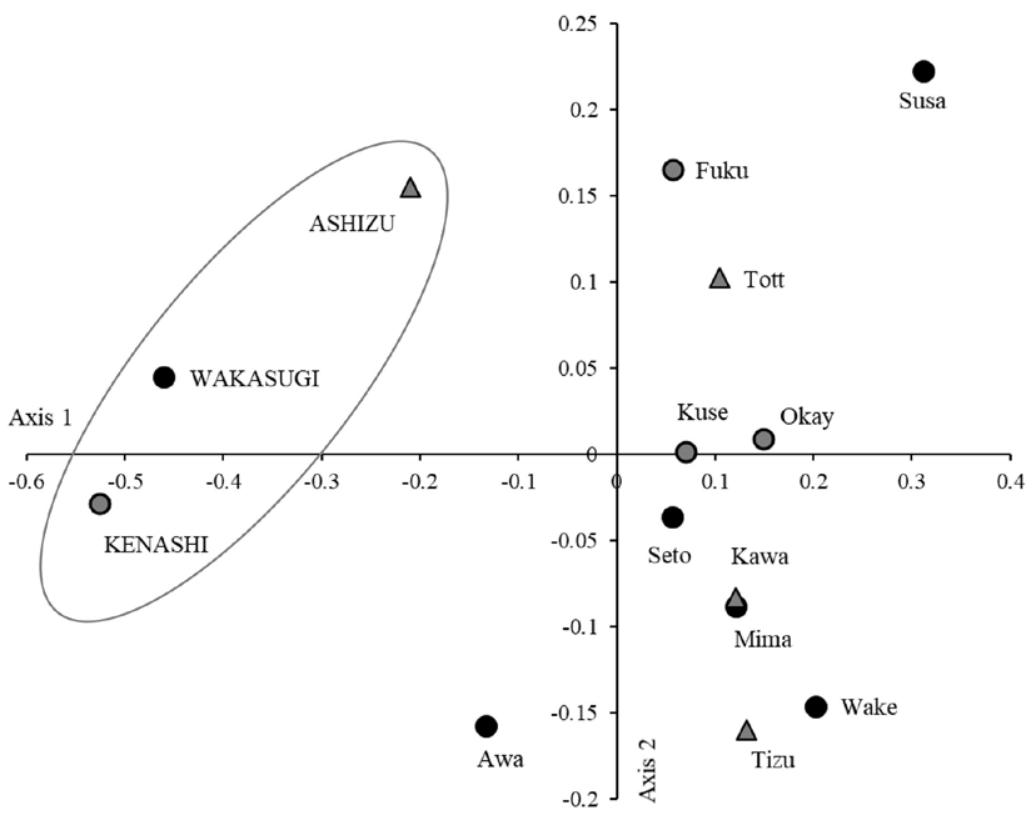

Fig. 3. Non-metric multidimensional scaling (NMDS) ordination plots of myxomycete communities from 14 survey sites. Symbols indicate three rivers, $\mathbf{\Lambda}$ : Sendai River, O: Yoshii River, $\mathbf{0}$ : Asahi River. Codes for survey site names are provided in Table 1. Site names written in capital letters and surrounded by an oval are river sources. Stress $=0.154$, coefficient of determination, $r^{2}=0.754$ for axis 1 and $r^{2}=0.050$ for axis 2 . 
Table 2. Tree traits, myxomycete occurrences and species diversity at survey sites. Codes for survey site names are provided in Table 1. Site names written in capital letters are river sources. Italics indicate data in a entire river.

Yoshii river

\begin{tabular}{|c|c|c|c|c|c|c|c|}
\hline Code & WAKA & Awak & Mima & Susa & Wake & Seto & Entire \\
\hline \multicolumn{8}{|l|}{ Tree traits } \\
\hline Tree samples & 13 & 10 & 11 & 10 & 10 & 10 & 64 \\
\hline Diameter of breast height $(\mathrm{cm})$ & 73 & 40 & 59 & 54 & 63 & 39 & 55 \\
\hline Bark p H & 3.6 & 3.8 & 3.7 & 3.8 & 3.9 & 3.8 & 3.8 \\
\hline Electric conductivity $(\mu \mathrm{S} / \mathrm{cm})$ & 320 & 268 & 354 & 344 & 305 & 338 & 321 \\
\hline \multicolumn{8}{|l|}{ Myxomycetes } \\
\hline Positive culture (\%) & 100 & 100 & 98 & 100 & 100 & 99 & 100 \\
\hline Mean species richness per tree & 7.5 & 7.1 & 5.5 & 6.1 & 5.2 & 5.4 & 6.1 \\
\hline Total species richness & 13 & 13 & 12 & 13 & 11 & 15 & 25 \\
\hline Chao-1 & 13 & 13 & 13 & 13 & 11 & 16 & 28 \\
\hline Species diversity $\left(H^{\prime}\right)$ & 2.27 & 2.19 & 2.02 & 2.17 & 1.84 & 2.16 & 2.51 \\
\hline Equitability $\left(J^{\prime}\right)$ & 0.88 & 0.85 & 0.79 & 0.84 & 0.77 & 0.80 & 0.78 \\
\hline
\end{tabular}

two NMDS axes (NMDS1 and NMDS2) and 11 environmental parameters (geographical, climate, landscape factors, and tree traits) are given in Table 4. NMDS1 was significantly correlated with distance from estuary $(r=-0.725, p<0.01)$, altitude $(r=-0.852, p<0.01)$, annualmeantemperature $(r=0.838$, $p<0.01)$, lowest monthly mean temperature $(r=0.877, p<0.01)$, and forest coverage $(r=-0.815$, $p<0.01)$. NMDS2 was not significantly correlated with any environmental parameter.

Myxomycete communities along NMDS1 were arranged according to species diversity $\left(H^{\prime}\right)$ ( $r=-0.526, p=0.057)$, equitability $\left(J^{\prime}\right)(r=-0.631, p$ $<0.05)$, and species richness per tree $(r=-0.776$, $p<0.01$ ). The upriver sites had higher species diversity than the downriver sites.

\section{Species spatial patterns}

Nine species were found to be indicators of five environmental gradients (Table 5). Distance from estuary was positively correlated with the relative abundances of Cribraria microcapa (Schrad.) Pers. ( $r=0.581, p<0.05)$, Cribraria minutissima Schw. $(r=0.674, p<0.01)$, Macbrideola argentea Nann.Bremek. \& Y. Yamam. ( $r=0.630, p<0.05)$, and Physarum nutans var. rubrum $(r=0.565, p<0.05)$, and negatively correlated with $P$. rigida $(r=-0.590$, $p<0.05)$ and Clastoderma debaryanum A. Blytt. $(r=-0.579, p<0.05)$. Altitude was positively correlated with Hemitrichia velutina Nann.-Bremek. \& Y. Yamam. $(r=0.886, p<0.01)$, M. argentea $(r=0.940, p<0.01)$, and $P$. nutans var. rubrum $(r=0.816, p<0.01)$, and negatively with $P$. rigida $(r=-0.637, p<0.05)$. Annual mean 
Asahi river

Sendai river

KENA Kuse Fuku Okay Entire ASHI Chiz Kawa Tott Entire

$\begin{array}{llllllllll}10 & 11 & 10 & 12 & 43 & 11 & 10 & 10 & 11 & 42 \\ 104 & 72 & 70 & 40 & 71 & 79 & 57 & 46 & 86 & 67 \\ 3.6 & 3.5 & 3.6 & 3.6 & 3.6 & 4.1 & 3.5 & 3.7 & 3.9 & 3.8 \\ 179 & 155 & 123 & 175 & 158 & 92 & 493 & 126 & 94 & 201\end{array}$

\begin{tabular}{llllllllll}
100 & 90 & 88 & 94 & 93 & 97 & 100 & 96 & 82 & 94 \\
\hline 7.8 & 4.4 & 4.8 & 4.6 & 5.4 & 6.2 & 4.7 & 4.7 & 3.9 & 4.9 \\
\hline 14 & 12 & 15 & 13 & 20 & 12 & 8 & 10 & 10 & 18 \\
15 & 15 & 15 & 16 & 26 & 12 & 9 & 10 & 11 & 19 \\
\hline 2.22 & 1.89 & 2.09 & 2.08 & 2.42 & 2.11 & 1.62 & 1.73 & 1.70 & 2.11 \\
0.84 & 0.76 & 0.77 & 0.81 & 0.81 & 0.85 & 0.78 & 0.75 & 0.74 & 0.73
\end{tabular}

temperature was positively correlated with $C$. debaryanum and $P$. rigida and negatively correlated with $H$. velutina, $M$. argentea, and $P$. nutans var. rubrum.

Forest coverage was positively correlated with M. argentea $(r=0.796, p<0.01)$, H. velutina $(r=0.731$, $p<0.01)$, and $P$. nutans var. rubrum $(r=0.651, p<0.01)$, whereas it was negatively correlated with $C$. debaryanum $(r=-0.608, p<0.05)$, Diderma chondrioderma (De Bary \& Rostaf.) G. Lister ( $r=-0.547, p<0.05)$, and Echinostelium minutum de Bary $(r=-0.547, p<$ $0.05)$. The latter three species were positively correlated with residential cover [E. minutum $(r=0.809, p<$ $0.01)$, D. chondrioderma $(r=0.764, p<0.01)$, and $C . d e$ baryanum $(r=0.547, p<0.05)]$. The landscape change from forest coverage to residential area strongly influenced the abundances of these three species.

\section{Discussion}

The dominant and common species of myxomycetes on C.japonica bark were identified across three river basins. There were two dominant species, $P$. rigida and $C$. confusa, which have previously been found to be common on C. japonica bark (Takahashi et al. 2018, 2020). Arcyria cinerea and P. nutans also frequently appeared in almost all survey sites, which was also observed in previous surveys (Takahashi et al. 2018, 2020).

The spatial distribution pattern of myxomycetes have suggested that it may relate to the ecological differences on a local scale (Stephenson et al. 2008). Cryptomeria japonica trees are distributed across river environments, from river source to estuary, and provide microhabitats for corticolous 
Table 3. Corticolous myxomycete species and abundances on the bark of living C. japonica trees at each survey sites. Numbers written in italics are the relative abundances in the total community. Codes for survey site names are provided in Table 1. Site names written in capital letters are river sources. The relative abundance of each species was indicated by rounded values.

\section{Yoshii river}

\begin{tabular}{|c|c|c|c|c|c|c|}
\hline Species & WAKA & Awak & Mima & Susa & Wake & Seto \\
\hline Paradiacheopsis rigida (Brândză) Nann.-Bremek. & 38 & 68 & 75 & 41 & 77 & 64 \\
\hline Cribraria confusa Nann.-Bremek. \&Y. Yamam. & 72 & 63 & 20 & 74 & 36 & 52 \\
\hline Arcyria cinerea (Bull.) Pers. & 31 & 60 & 30 & 28 & 8 & 45 \\
\hline Enerthenema melanospermum T. Macbr. \& G. W. Martin & 41 & 25 & 36 & 12 & 63 & 49 \\
\hline Physarum nutans Pers. & 74 & 50 & 31 & 20 & 8 & 12 \\
\hline Macbrideola argentea Nann.-Bremek. \&Y. Yamam. & 91 & 4 & & & & \\
\hline Hemitrichia velutina Nann.-Bremek. \&Y. Yamam. & 31 & 3 & & & & \\
\hline Cribraria microcarpa (Schrad.) Pers. & 22 & 13 & 2 & 1 & & 20 \\
\hline $\begin{array}{l}\text { Physarum nutans var. rubrum (Nann.-Bremek. } \\
\text { \&Y. Yamam.) Chao H. Chung }\end{array}$ & 65 & & & & & 10 \\
\hline Cribraria minutissima Schwein. & 16 & 47 & & & 5 & 1 \\
\hline Comatricha pulchella (C. Bab.) Rostaf. & 10 & & 2 & 41 & 9 & \\
\hline Comatricha laxa Rostaf. & & 4 & 21 & & 13 & 9 \\
\hline Clastoderma debaryanum Blytt & & & 17 & 9 & 7 & 19 \\
\hline Enerthenema papillatum (Pers.) Rothtaf. & & & & 18 & & 8 \\
\hline Diderma chondrioderma (de Bary \& Rostaf.) G. Lister & 3 & & 6 & & & \\
\hline Comatricha elegans (Racib.) G. Lister & & 14 & & 3 & 7 & 2 \\
\hline Macbrideola confusa Nann.-Bremek. \&Y. Yamam. & & 17 & & 7 & & \\
\hline Enerthenema berkeleyanum Rostaf. & & & & 21 & & \\
\hline Licea variabilis Schrad. & & & & 3 & & \\
\hline Echinostelium minutum de Bary & & & 1 & & & 2 \\
\hline Paradiacheopsis solitalia Nann.-Bremek. \&Y. Yamam. & & 5 & & & & \\
\hline Lycogala exigiuum Morgan & & & 2 & & & 1 \\
\hline Licea kleistobolus G. W. Martin & 1 & & & & & \\
\hline Stemonitopsis curiosa Nann.-Bremek. \&Y. Yamam. & & & & & & 1 \\
\hline Hemitrichia minor G. Lister & & & & & 1 & \\
\hline \multicolumn{7}{|l|}{ Macbrideola cornea (G. Lister \& Cran) Alexop. } \\
\hline \multicolumn{7}{|l|}{$\begin{array}{l}\text { Paradiacheopsis fimbriata (G. Lister \& } \\
\text { Cran) Hertel ex Nann.-Bremek. }\end{array}$} \\
\hline Total abundance & 495 & 373 & 243 & 278 & 234 & 295 \\
\hline
\end{tabular}




\begin{tabular}{|c|c|c|c|c|c|c|c|c|c|}
\hline \multicolumn{4}{|c|}{ Asahi river } & \multicolumn{4}{|c|}{ Sendai river } & \multirow{2}{*}{ Total } & \multirow{2}{*}{$\begin{array}{l}\text { Relative } \\
\text { abundance } \\
(\%)\end{array}$} \\
\hline KENA & Kuse & Fuku & Okay & ASHI & Chiz & Kawa & Tott & & \\
\hline 30 & 65 & 70 & 51 & 55 & 83 & 85 & 54 & 856 & 22 \\
\hline 52 & 30 & 24 & 44 & 18 & 49 & 61 & 47 & 642 & 17 \\
\hline 30 & 29 & 48 & 29 & 46 & 15 & 32 & 48 & 479 & 12 \\
\hline 3 & 26 & 7 & 43 & 35 & 47 & 28 & 11 & 426 & 11 \\
\hline 3 & 3 & 8 & 13 & 17 & 1 & 6 & 1 & 247 & 6 \\
\hline 72 & & 5 & & 46 & & 1 & 2 & 221 & 6 \\
\hline 33 & 3 & 7 & & 55 & 1 & & & 133 & 3 \\
\hline 39 & 19 & 3 & & & 12 & & & 131 & 3 \\
\hline 23 & & & & 14 & & & & 112 & 3 \\
\hline 33 & 1 & 2 & 4 & & & & 1 & 110 & 3 \\
\hline \multirow[t]{4}{*}{7} & 7 & 6 & & & & & 14 & 96 & 2 \\
\hline & & & 1 & & 21 & 19 & 3 & 91 & 2 \\
\hline & 1 & 8 & 13 & 6 & & 2 & 6 & 88 & 2 \\
\hline & 6 & 30 & 6 & & & & & 68 & 2 \\
\hline \multirow[t]{4}{*}{1} & & 4 & 19 & & & 5 & & 38 & 1 \\
\hline & & & & & & 4 & & 30 & 1 \\
\hline & & & & & & & & 24 & 1 \\
\hline & & & & & & & & 21 & 1 \\
\hline \multirow[t]{7}{*}{6} & & 2 & & 4 & & & & 15 & 0.4 \\
\hline & 1 & 2 & 5 & 1 & & & & 12 & 0.3 \\
\hline & & & & 2 & & & & 7 & 0.2 \\
\hline & & & & & & & & 3 & 0.1 \\
\hline & & & 1 & & & & & 2 & 0.1 \\
\hline & & & & & & & & 1 & 0.0 \\
\hline & & & & & & & & 1 & 0.0 \\
\hline 1 & & & & & & & & 1 & 0.0 \\
\hline & & & 1 & & & & & 1 & 0.0 \\
\hline
\end{tabular}


Table 4. Correlation coefficients between the first two NMDS axes scores and environmental variables, tree traits, and myxomycete diversity.

\begin{tabular}{|c|c|c|c|}
\hline & Axis1 & & Axis2 \\
\hline \multicolumn{4}{|l|}{ Geographic factors } \\
\hline North latitude & -0.385 & & 0.006 \\
\hline East longitude & 0.097 & & -0.067 \\
\hline Distance from estuary & -0.725 & $* *$ & -0.078 \\
\hline Altitude & -0.852 & ** & 0.195 \\
\hline
\end{tabular}

\section{Climatic factors}

\begin{tabular}{llll}
\hline Annual mean temperature & 0.838 & $* *$ & -0.148 \\
\hline Precipitation & -0.348 & & -0.024 \\
\hline
\end{tabular}

\section{Land-use types}

\begin{tabular}{|c|c|c|c|}
\hline Forest coverage & -0.815 & $* *$ & 0.102 \\
\hline Farm coverage & 0.468 & & -0.287 \\
\hline Residence coverage & 0.511 & & 0.106 \\
\hline
\end{tabular}

\section{Tree traits}

\begin{tabular}{lll}
\hline BarkpH & 0.072 & 0.210 \\
\hline Electrical conductivity & 0.178 & -0.445 \\
\hline
\end{tabular}

\begin{tabular}{llll} 
Myxomycete diversity & & & \\
\hline Species richness per tree & -0.776 & $* *$ & -0.015 \\
\hline Total species richness & -0.251 & 0.285 \\
\hline Species diversity $\left(H^{\prime}\right)$ & -0.526 & 0.318 \\
\hline Equitability $\left(J^{\prime}\right)$ & -0.631 & $*$ & 0.192
\end{tabular}

Significance ${ }^{* *} p<0.01,{ }^{*} p<0.05$

myxomycetes. Thus, it was revealed in this study that diverse climates and ecological differences exist along a river basin due to topographical and geographical differences influenced myxomycete distribution along river basins. It has been reported that altitudinal differences influence myxomycete distribution on C. japonica bark (Takahashi 2017). The distribution of three species specialised for mountain forests in the present study, M. argentea,
H. velutina, and P. nutans var. rubrum, were negatively affected by forest depletion that occurred as the rivers reached lower elevations (i.e., highly populated areas or farmland). Conversely, $P$. rigida preferred the lower altitudes found downstream. Decreasing forest and increasing residential area resulted in an increase in C. debaryanum, D. chondrioderma, and $E$. minutum abundance, which suggests that these species prefer urban environments. These species are likely to be sensitive to local geography and topography. The present study revealed that myxomycetes are not ubiquitously distributed across river basins but inhabit different regions depending on geographical features, including land-use changes and human activities. The river basins likely function as an ecological corridor, creating habitat diversity and affecting species diversity for myxomycetes in those environments.

The distribution of corticolous myxomycetes on C. japonica bark may have been influenced by a number of environmental factors, such as topology, geographical location, temperature, and land-use type (i.e., artificial environments). In this study, forest coverage along the river basins had the greatest effect on myxomycetes. The highest species diversity was found in the natural forests in the mountains, which provided habitats for specialists, but degradation of forest coverage affected the myxomycete community structure and influenced the distribution of several species. As landscape types changed from forest to urban or farmland, the abundance of corticolous myxomycetes decreased, resulting in lower species densities on trees. Natural forests along river reaches maintained higher species diversities of corticolous myxomycetes on C. japonica barks, whereas the downstream degradation of forest correlated with changes to dwelling myxomycete species. It is likely that the barks of $C$. japonica in natural forests that existed as refuges of the last ice age preserved higher myxomycete diversity than those in the peripheral planted forests (Takahashi 2020).

The variation in landscape composition affected the inhabitation of myxomycete species and the community structure. The land uses were quite different near the estuary for each river, i.e., the Seto site on the Yoshii River was dominated by farmland, the Okay site on the Asahi River was dominated by urban areas, and the Tott site on the Sendai River 
Table 5. Correlation coefficients between the relative abundances of dominant species and environmental variables along rivers.

\begin{tabular}{|c|c|c|c|c|c|c|c|c|c|c|}
\hline \multirow[b]{3}{*}{ Clastoderma debaryanum } & \multirow{2}{*}{\multicolumn{2}{|c|}{$\begin{array}{l}\text { Distance } \\
\text { from } \\
\text { estuary }\end{array}$}} & \multirow{2}{*}{ Altitude } & & \multirow{2}{*}{$\begin{array}{l}\text { Annual mean } \\
\text { temperature }\end{array}$} & & \multicolumn{4}{|l|}{ Coverage } \\
\hline & & & & & & & Forest & & Residence & \\
\hline & -0.579 & * & -0.514 & & 0.577 & $*$ & -0.608 & $*$ & 0.547 & * \\
\hline Cribraria microcarpa & 0.581 & * & 0.277 & & -0.335 & & 0.348 & & -0.306 & \\
\hline Cribraria minutissima & 0.674 & $* *$ & 0.292 & & -0.326 & & 0.455 & & -0.307 & \\
\hline Diderma chondrioderma & -0.307 & & -0.271 & & 0.425 & & -0.547 & * & 0.764 & ** \\
\hline Echinostelium minutum & -0.368 & & -0.269 & & 0.407 & & -0.547 & $*$ & 0.809 & ** \\
\hline Hemitrichia velutina & 0.357 & & 0.886 & ** & -0.869 & ** & 0.731 & $* *$ & -0.448 & \\
\hline Macbrideola argentea & 0.630 & * & 0.914 & $* *$ & -0.894 & ** & 0.796 & $* *$ & -0.485 & \\
\hline Paradiacheopsis rigida & -0.590 & * & -0.637 & * & 0.579 & $*$ & -0.515 & & 0.298 & \\
\hline $\begin{array}{l}\text { Physarum nutans var. } \\
\text { rubrum }\end{array}$ & 0.565 & * & 0.816 & ** & -0.770 & ** & 0.651 & $*$ & -0.448 & \\
\hline
\end{tabular}

was dominated by forest adjacent to residential areas (Fig. 2). Species richness along the Yoshi, Asahi, and Sendai Rivers were 26, 20, and 18 species, respectively, and the species diversity $\left(H^{\prime}\right)$ was 2.51 , 2.42, and 2.11, respectively. The Yoshii River had the highest species diversity in the basin, which exhibited a steady decrease in forest coverage from reach to estuary and consisted of heterogeneous landscapes. These geographical and landscape differences along a river basin likely have ecological effects for myxomycete species and the community. The river basin constitutes a corridor for myxomycete habitats.

Previously, the main factors thought to be affecting the occurrence of myxomycetes were temperature and moisture (Alexopoulos 1963). In a Japanese archipelago, geographical distribution of myxomycetes was primarily driven by air temperature (Takahashi \& Hada 2010; Takahashi \& Harakon 2018; Takahashi et al. 2018). In this study, the altitudinal difference from the lowest to the highest site was approximately $1,100 \mathrm{~m}$, resulting in a temperature difference of approximately $7{ }^{\circ} \mathrm{C}$. Large differences between the river source communities and downstream communities were observed along NMDS1 scores, as shown in Fig. 3. The separated clusters may be due to the temperature differences of approximately $4{ }^{\circ} \mathrm{C}$ between river sources and neighbouring sites. This indicates the potential for climate warming to alter corticolous myxomycete community structures in these regions.

There have been several studies on the effects of human activities on myxomycete communities. Myxomycetes are influenced by air pollution in large European cities such as Helsinki (Härkönen \& Vänskä 2004) and Madrid (Wrigley de Basanta 2000); however, it is unclear if urbanisation influences corticolous myxomycetes. In Sydney, myxomycete diversity is driven by factors at the substrate level in urban parks, but not by the park's location within the city (inner city or semi-urban) (Hosokawa et al. 2019). Differences in myxomycete communities have been observed between agricultural plantations (Redeña-Santos et al. 2017) and old-growth forests in the Philippines (Dagamac et al. 2015), and there is evidence that forest disturbance decreases myxomycete richness and fruiting in the 
Amazon basin (Rojas \& Stephenson 2013). In the current study, forest degradation had a major effect on myxomycete communities on $C$. japonica bark. This is likely not due to substrate loss or change, but rather to change of microenvironments in air flow, temperature, and humidity as a result of deforestation. It remains unclear whether bark-dwelling myxomycetes are affected by physical environmental factors or biotic interactions that result from forest loss. The association of myxomycete diversity with environmental changes in geography, climate, and anthropogenic activity require further research because myxomycetes play important functions in the ecological control of decomposition and nutrient cycling in local terrestrial ecosystems.

\section{Acknowledgements}

The present study was supported by a grant from the River Environment Foundation (Issue number 2019-5411-002). I would like to thank the biology club members at Okayama Science University High School, Miss Ayane Fujikawa, Mr. Harumiti Jo, Miss Nanami Hori, and Mr. Yuya Yamasaki for their assistance with tree bark sampling and moist chamber culturing.

\section{References}

Aguilar, M., Fiore-Donno, A.M., Lado, C. \& Cavalier-Smith, T. 2014: Using environmental niche models to test the "everything is everywhere" hypothesis for Badhamia.

The ISME Journal 8: 737-745. doi: 10.1038/ismej.2013.183

Alexopoulos, C.J. 1963: The myxomycetes II.

The Botanical Review 29: 1-78.

Bray, J.R. \& Curtis, J.T. 1957: An ordination of upland forest communities of southern Wisconsin. Ecological Monographs 27: 325-349. doi: org/10.2307/1942268

Chao, A. 1984: Nonparametric estimation of the number of classes in a population.

Scandinavian Journal of Statistics 11: 265-270.
Dagamac, N.H.A., Novozhilov, Y.K., Stephenson, S.L., Lado, C., Rojas, C., de la Cruz, T. E.E., Unterseher, M. \& Schnittler, M. 2017: Biogeographical assessment of myxomycete assemblages from neotropical and Asian palaeotropical forests. Journal of Biogeography 44: 1524-1536. doi: org/10.1111/jbi.12985

Dagamac, N.H.A., de la Cruz, T.E.E., Rea-Maminta, M.A.D., Aril-Dela Cruz, J.V. \& Schnittler, M. 2015: Rapid assessment of myxomycete diversity in the Bicol Peninsula,

Philippines. Nova Hedwigia 100: 31-46. doi: 10.1127/nova_ hedwigia/2015/0252

Estrada-Torres, A., Wrigley de Basanta, D. \& Lado, C. 2013: Biogeographic patterns of the myxomycete biota of the Americas using a parsimony analysis of endemicity. Fungal Diversity 59: 159-177. doi: 10.1007/s13225-012-0209-2

Gilbert, H. C. \& Martin, G. W. 1933: Myxomycetes found on the bark of living trees. University of lowa Studies in Natural History 15: 3-8.

Hammer, Ø., Harper, D.A.T. \& Ryan, P.D. 2001: PAST: Paleontological statistics software package for education and data analysis. Palaeontologia Electronica 4: 9.

Downloaded from http://folk.uio.no/ohammer/past/.

Date accessed: 1 May 2020.

Härkönen, M. \& Vänskä, H. 2004: Corticolous myxomycetes and lichens in the botanical garden in Helsinki, Finland: Comparison after decades of recovering from air pollution. Systematics and Geography of Plants 74: 183-187. doi: $10.2307 / 3668567$

Hosokawa, A., Reid, C.R. \& Latty, T. 2019: Slimes in the city: The diversity of myxomycetes from inner-city and semiurban parks in Sydney, Australia. Fungal Ecology 39: 37-44. doi: 10.1016/j.funeco.2018.11.004

Keller, H.W. \& Brooks, T.E. 1973: Corticolous myxomycetes I: Two new species of Didymium. Mycologia 65: 286-294. doi.org /10.1080/00275514.1973.12019438

Kenkel, N.C. \& Orlóci, L. 1986: Applying metric and nonmetric multidimensional scaling to ecological studies: Some new results. Ecology 67: 919-928. 10.2307/1939814

Lado, C. 2005-2020: An online nomenclatural information system of Eumycetozoa. Downloaded from http://eumycetozoa.com/data/index.php.

Date accessed: 1 May 2020.

Lado, C., Wrigley de Basanta, D., Estrada-Torres, A. \& Stephenson S.L. 2016: Myxomycete diversity in the coastal desert of Peru with emphasis on the lomas formations. Anales del Jardín Botánico de Madrid 73: e032. doi: 10.3989/ajbm.2436 
Macabago, S.A., Dagamac, N.H.A, Cruz, T.E.D., \& Stephenson, S.L. 2017: Implication of the role of dispersal on the occurrence of litter-inhabiting myxomycetes in different vegetation types after a disturbance: A case study in Bohol Islands, Philippines. Nova Hedwigia 104: 221-236.

doi: 10.1127/nova_hedwigia/2016/0391

Novozhilov, Y. \& Schnittler, M. 2008: Myxomycete diversity and ecology in arid regions of the Great Lake Basin of western Mongolia. Fungal Diversity 30: 97-119.

Novozhilov, Y., Okun, M.V., Erastova, D.A., Shchepin, O.N., Zemlyanskaya, I.V. \& Schnittler, M. 2013: Description, culture and phylogenetic position of a new xerotolerant species of Physarum. Mycologia 105: 1535-1546. doi: 10.3852/12-284

Novozhilov, Y., Erastova, D.A., Shchepin, O.N., Schnittler, M., Alexandrova, A.V., Popov, E.S. \& Kuznetsov, A.N. 2017: Myxomycetes associated with monsoon lowland tropical forest in southern Vietnam. Nova Hedwigia 104: 143-182. doi: 10.1127/nova_hedwigia/2016/0395

Novozhilov, Y., Shchepin, O.N., Alexandrova, A.V., Popov, E.S., \& Dagamac, N.H.A. 2018: Altitudinal patterns of diversity of myxomycetes (Myxogastria) across tropical forests of southern Vietnam. Protistology 12: 73-80.

doi: 10.21685/1680-0826-2018-12-2-2

Redeña-Santos, J.C., Dunca, J.A.U., Thao, D.V., \& Dagamac, N.H.A. 2017: Myxomycetes occurring on selected agricultural leaf litters. Studies in Fungi 2: 171-177. doi: 10.5943/sif/2/1/19

Rollins, A.W. \& Stephenson, S.L. 2011: Global distribution and ecology of myxomycetes. Current Topics in Plant Biology 12: 1-14.

Rojas, C. \& Stephenson, S.L. 2013: Effect of forest disturbance on myxomycete assemblages in the southwestern Peruvian Amazon. Fungal Diversity 59: 45-53.

doi: 10.1007/s13225-012-0181-x

Schnittler, M., Stephenson, S.L. \& Novozhilov, Y.K. 2000 : Ecology and world distribution of Barbeyella minutissima (Myxomycetes). Mycological Research 104: 1518-1523. doi: org/10.1017/S0953756200002975

Schnittler, M. \& Tesmer, J. 2008: A habitat colonisation model for spore-dispersed organisms-Does it work with eumycetozoans? Mycological Research 112: 697-707. doi: 10.1016/j.mycres.2008.01.012

Schnittler, M., Dagamac, N.H.A. \& Novozhilov, Y.K. 2017: Biogeographical patterns in myxomycetes. In: Stephenson, S.L. \& Rojas, C. (eds). Myxomycetes: Biology, systematics, biogeography, and ecology, 299-331. Academic Press, London.
Shannon, C.E. \& Weaver, W. 1963: The mathematical theory of communication. University of Illinois Press: Urbana, Illinois.

Stephenson, S.L. 1989: Distribution and ecology of myxomycetes in temperate forests. II. Patterns of occurrence on bark surface on living trees, leaf litters, and dung. Mycologia, 81: 608-621. doi: 10.2307/3760136

Stephenson, S.L. 2011: From morphological to molecular: Studies of myxomycetes since the publication of the Martin and Alexopoulos (1969) monograph. Fungal Diversity 50: 21-34. doi: 10.1007/s13225-011-0113-1

Stephenson, S.L., Kalyanasundaram, I. \& Lakhanpal, T.N. 1993: A comparative biogeographical study of myxomycetes in the mid-Appalachians of eastern North America and two regions of India. Journal of Biogeography 20: 645-657. doi: org/10.2307/2845520

Stephenson, S.L., Schnittler, M. \& Novozhilov, Y.K. 2008: Myxomycete diversity and distribution from the fossil record to the present. Biodiversity and Conservation 17: 285-301. doi: 10.1007/s10531-007-9252-9

Takahashi, K. 2017: Altitudinal distribution patterns of myxomycete species growing on bark of Cryptomeria japonica tree in warm temperate zone of Japan. Hikobia 17: 207-217.

Takahashi, K. \& Harakon, Y. 2016: Ecological patterns of wood-inhabiting myxomycetes in a natural forest of the Kamikochi, the Hida mountain range, central Japan. The Journal of Japanese Botany 91: 205-217.

Takahashi, K. \& Harakon, Y. 2018: Biogeographical assessment of corticolous myxomycetes on living Cryptomeria japonica in Japanese mainland and satellites. Hikobia 17: 285-297.

Takahashi, K., Harakon, Y. \& Fukasawa, Y. 2018: Geographical distribution of myxomycetes living on Cryptomeria japonica bark in Japan. Mycoscience 59: 379-2385. doi: org/10.1016/j. myc.2018.02.005

Takahashi, K., Yamasaki, Y., Minami, K. \& Yabumki, N. 2020: Biogeographical assessment of corticolous myxomycetes on the living tree bark of Cryptomeria japonica in a region of western Japan. Biogeography 22: 35-42. doi: org/10.11358/ biogeo. 22.35

Wrigley de Basanta, D. 2000: Acid deposition in Madrid and corticolous myxomycetes. Stapfia 73: 113-120.

Yamamoto, Y. 1998: The myxomycete biota of Japan. Toyo Shorin Publishing Co.: Tokyo. (in Japanese) 